\title{
Long-term trends in the annual groundwater recharge estimates using the water table fluctuation method
}

\author{
$\underline{X . S h i}^{a}$, R. S. Crosbie ${ }^{b}$ and J. Vaze ${ }^{a}$ \\ ${ }^{a}$ CSIRO Land and Water, Canberra, Australian Capital Territory, Australia \\ ${ }^{b}$ CSIRO Land and Water, Glen Osmond, South Australia, Australia \\ Email: Xiaogang.Shi@csiro.au
}

\begin{abstract}
Groundwater recharge is critical for sustainable water resource planning and modelling fluid and contaminant transport within the subsurface. Unfortunately, direct groundwater measurements are often too short to investigate long-term trends for many regions in Australia. Over the past, a number of methods have been developed to estimate groundwater recharge over different temporal and spatial scales. Among the most widely used techniques for estimating recharge, the water table fluctuation (WTF) method has been applied in numerous studies. In this study, we use the WTF method to estimate annual groundwater recharge at 438 groundwater monitoring bores in South Australia and analyse long-term annual groundwater recharge trends using the nonparametric Mann-Kendall trend test. The results indicate that the spatially averaged annual groundwater recharge has declined significantly with a trend of $-0.92 \mathrm{~mm} /$ year for the period 1970 2012. Similar trend tests for the 237 groundwater monitoring bores with longer data records exhibit that 161 bores have downward trends of which 103 bores are statistically significant, whereas 44 bores have upward trends and 15 of them are statistically significant. Moreover, a linear extrapolation of annual groundwater recharge trend suggests that the mean will reach the lowest recorded annual recharge in history (2006 drought) by 2058 if the recent climatic trends continue over a longer period, indicating a potential threat to the hydrological and ecological regimes. Furthermore, the correlation analysis demonstrates that the dominating downward trends in annual groundwater recharge are affected by the large-scale hydroclimate variables (e.g. rainfall) in South Australia.
\end{abstract}

Keywords: Annual groundwater recharge, water table fluctuation method, Mann-Kendall trend test 


\section{INTRODUCTION}

Groundwater recharge is critical for sustainable water resource planning and modelling fluid and contaminant transport within the subsurface (Scanlon et al., 2003; Healy, 2010). Unfortunately, direct groundwater measurements are often too short to evaluate long-term temporal variations for many regions in Australia (Zhang et al., 2014). Over the past, a number of methods have been proposed and tested to estimate groundwater recharge over different temporal and spatial scales (Meinzer and Stearns, 1929; Anderson, 1945; Wood, 1999; Healy and Cook, 2002; Crosbie et al., 2005). Among the most widely used techniques, the water table fluctuation (WTF) method has been applied in numerous studies to estimate gross groundwater recharge (Rasmussen and Andreasen, 1959; Gerhart, 1986; Hall and Risser, 1993; Crosbie et al., 2005; Lee et al., 2005; Coes et al., 2007; Delin et al., 2007; Cartwright and Simmonds, 2008; Radford et al., 2009; Cuthbert, 2010; Crosbie et al., 2015). Therefore, we used the WTF method to estimate annual groundwater recharge time series across the study domain and analyse long-term trends in annual records for the period 1970-2012.

The main objective of this study is to evaluate long-term trends in the annual groundwater recharge estimates using the WTF method. In Section 2, we describe the study domain. In Section 3, we focus on the methods used for undertaking the analyses. Subsequently, we examine long-term trends in the annual groundwater recharge estimates using the nonparametric Mann-Kendall trend test. To identify possible causes of changing groundwater recharge, we also evaluate the annual rainfall trend and assess the relationship between annual groundwater recharge and annual rainfall across the study domain using the Pearson's product moment correlation coefficient in Section 4. The findings are summarised in Section 5.

\section{STUDY DOMAIN}

The study area is in South Australia, and lies within the Otway and Murray Basins (Figure 1). The area is the outline of the tertiary confined sands aquifer of the Dilwyn Formation and has a gentle relief with the highest elevation in the northeast with the land sloping away toward the south and west to the coast with some variation due to the dune/flat systems (Crosbie et al., 2015).

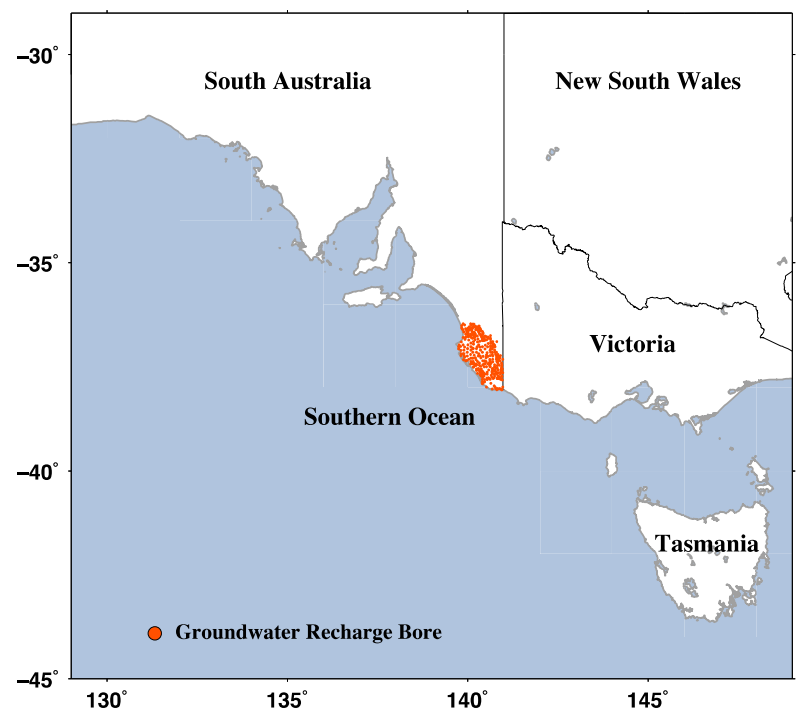

Figure 1. Location map for 438 groundwater monitoring bores in South Australia.

The climate is water-limited Mediterranean with annual rainfall greatest in the south and decreasing inland (Jones et al., 2009) and potential evapotranspiration greater than rainfall everywhere on an annual basis (Donohue et al., 2010). The region has wet winters when potential evapotranspiration is low and, thus, has considerable recharge to the groundwater system, which is the only source of water in the region (Crosbie et al., 2015). Very little surface runoff is generated, any runoff being quickly infiltrated into the groundwater through thousands of karst features in the landscape, but a minor source of recharge regionally (Leaney and Herczeg, 1995). Additionally, the study region has a long history of field investigations for groundwater 
recharge and the majority of these recharge estimates are point-based estimates (Anderson, 1945; Allison and Hughes, 1978; Brown et al., 2006; Wohling, 2008; Wood, 2010; Crosbie et al., 2015).

\section{METHODS}

The WTF method for estimating groundwater recharge was first proposed by Meinzer and Stearns (1929), which is based on the premise that the rise in the groundwater level in unconfined aquifers is due to recharge water reaching the water table. Among the most widely used techniques for estimating recharge, the WTF method has been applied in many previous studies (e.g. Rasmussen and Andreasen, 1959; Gerhart, 1986; Hall and Risser, 1993; Crosbie et al., 2005; Delin et al., 2007; Crosbie et al., 2015). By using the WTF method, the annual groundwater recharge time series were estimated for the period 1970 to 2012 at the 438 boreholes in South Australia. The recharge estimates vary between 2 and $498 \mathrm{~mm} / \mathrm{year}$ with an average of 86 $\mathrm{mm} /$ year.

To examine long-term trends in annual groundwater recharge, we used the nonparametric Mann-Kendall trend test (Mann, 1945) for trend significance, and the Sen method (Sen, 1968) to estimate trend slope. A 5\% significance level (two-sided test) was specified. In addition, the Pearson's product-moment correlation coefficient was used to assess the relationship between the WTF annual groundwater recharge estimates and annual rainfall. The correlation coefficient $(r)$ is statistically significant at a level of $p<0.025$ (two-sided test). The correlation analysis undertaken in this study provides the opportunity to identify possible causes of long-term trends in annual groundwater recharge across the study domain.

\section{RESULTS}

The spatially averaged annual groundwater recharge with a 43-year record starting from 1970 to 2012 was calculated from the 438 groundwater monitoring bores across the study domain. The results from the nonparametric Mann-Kendall trend test show that the spatially averaged annual groundwater recharge has declined significantly $(p<0.005)$ with a trend slope of $-0.92 \mathrm{~mm} / \mathrm{year}^{2}$ over the study period (Figure 2 ). In this analysis, the trend in the spatially averaged annual groundwater recharge is not biased as it is a superposition in time and space and the sample size of groundwater recharge bores is large enough.

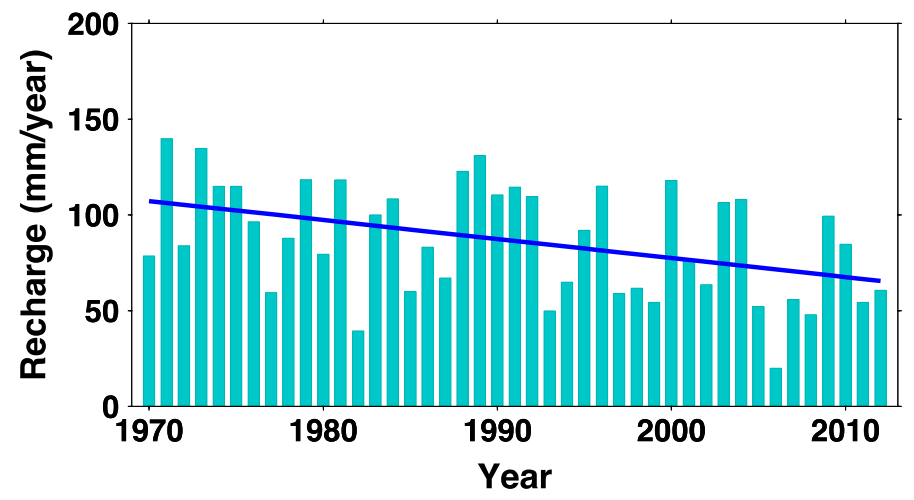

Figure 2. The annual groundwater recharge spatially averaged from 438 bores in South Australia has a statistically significant downward trend (blue solid line) from 1970 to 2012.

Due to the discontinuous monitoring records, some bores may not have a full length of groundwater recharge data from 1970 to 2012, which resulted in the variable number of bores contributing to the spatial average of annual groundwater recharge for each year. To get a better understanding for the temporal changes of annual groundwater recharge across the study domain, we also need to analyse the long-term recharge trends for those individual groundwater bores. Among the 438 bores in South Australia, we found that 237 bores had annual recharge data records longer than 20 years. The nonparametric Mann-Kendall trend test was applied to these bores with record length varying between 20 and 43 years, with an average length of 30 years.

Figure 3 illustrates the annual groundwater recharge trends and their corresponding data periods for the 237 bores in South Australia. Each line represents a period for which the trend slope is given by the colour of the 
line, while the exact period is given by the length of the line that starts and ends at the start and end of the period. The colour bar under the figure shows the trend magnitude and direction. The results indicate that 161 bores have downward trends in annual groundwater recharge, of which 103 bores (64\%) are statistically significant at 0.025 level of significance. In addition, there are 44 bores with upward trends and $15(34 \%)$ out of the 44 bores are statistically significant at 0.025 significance level, whereas the trends are neutral at 32 bores for the periods between 1970 and 2012. Overall, the downward trends (68\% of the 237 bores) in annual groundwater recharge basically dominate the temporal changes across the study domain, which are consistent with our findings in the spatially averaged annual groundwater recharge over the study period.

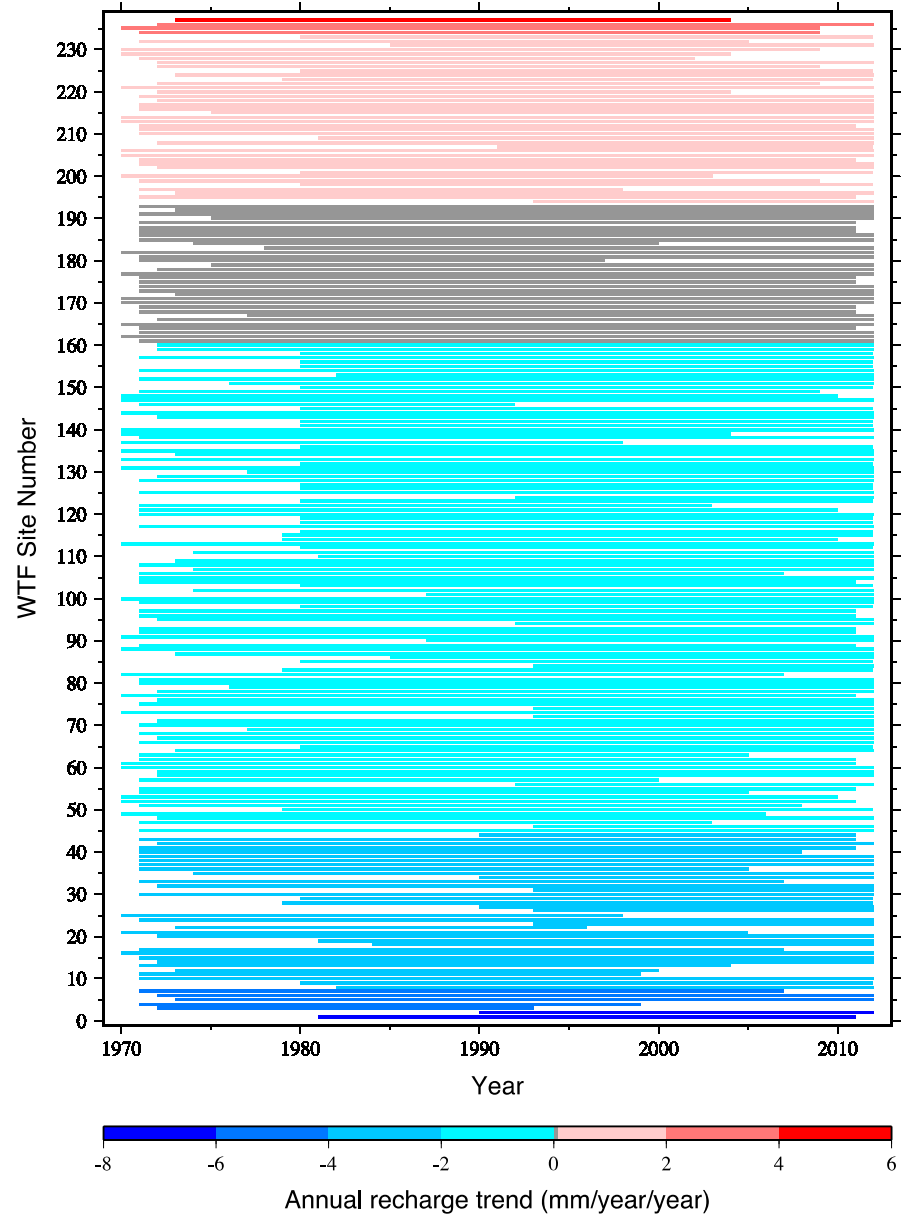

Figure 3. The nonparametric Mann-Kendall trends and their corresponding data periods for the 237 groundwater bores with data records longer than 20 years in South Australia.

As showed in Figure 2, the spatially averaged annual groundwater recharge exhibits a statistically significant decreasing trend over 43 years, resulting in a 38\% groundwater recharge reduction from $107 \mathrm{~mm} / \mathrm{year}$ in 1970 to $66 \mathrm{~mm} /$ year in 2012. When the linear trend line is extrapolated into the future, the annual groundwater recharge would attain $20 \mathrm{~mm} /$ year by 2058 (Figure 4), reaching the lowest record of annual groundwater recharge in history (2006 drought) and implying a potential threat to the hydrological and ecological regimes in the study area if the recent climatic trends continue over a longer period. This is more severe than the previous climate change projection, in which the dry projection was $42 \%$ reduction for 2050 relative to 1990 (Crosbie et al., 2013). 


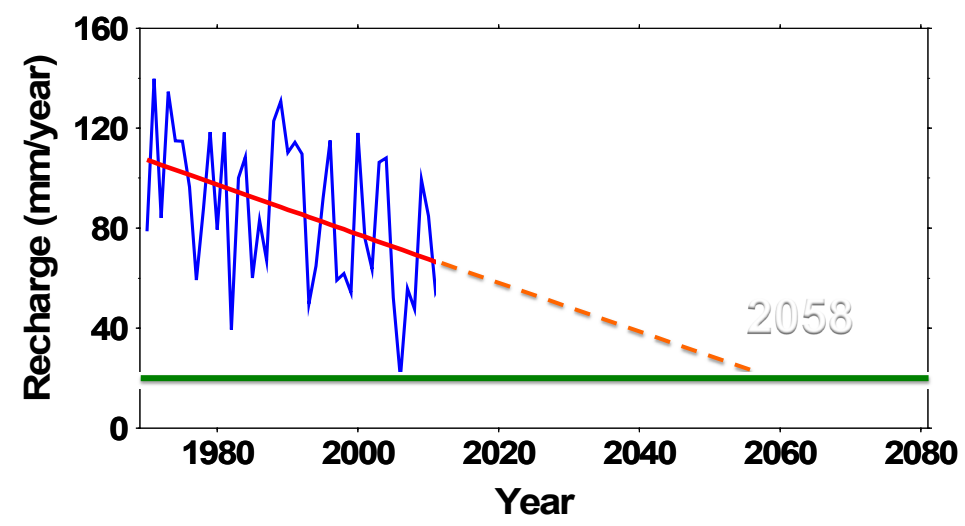

Figure 4. Time series of spatially averaged annual groundwater recharge (blue solid line) calculated from the 438 bores in South Australia with the linear trend line from 1970 to 2012 (red solid line) and its linear extension for the period of 2013-2058 (orange dashed line).

Similar to annual groundwater recharge, the spatially averaged annual rainfall was also calculated for the 438 bores across the study domain. The nonparametric Mann-Kendall trend test shows that the 43-year annual rainfall has a decreasing trend of $-1.23 \mathrm{~mm} / \mathrm{year}$ at a non-significant level of $p<0.10$ during 1970-2012. This decline in annual rainfall across the study domain is consistent with the temporal change in annual groundwater recharge.

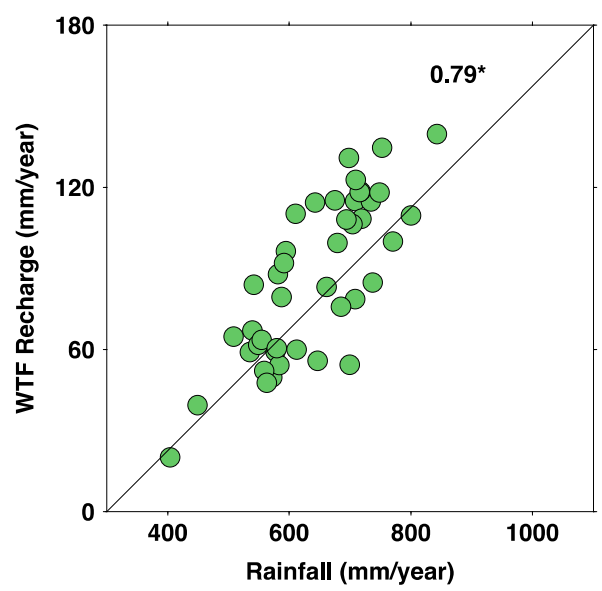

Figure 5. Scatterplot of spatially averaged annual groundwater recharge versus annual rainfall across the study domain in South Australia for the period 1970-2012. The sign of star means that the correlation has a significance level $p<0.005$.

Figure 5 shows the relationship between annual groundwater recharge and annual rainfall spatially averaged from the 438 bores in South Australia for the period 1970-2012. Obviously, annual groundwater recharge is highly correlated $(r=0.79)$ with annual rainfall, which is statistically significant at a level of $p<0.005$ with a two-sided test. As described in Section 2, the climate in the study domain is water-limited Mediterranean with potential evapotranspiration greater than rainfall everywhere on an annual basis (Donohue et al., 2010). Also, the groundwater system is the only source of water, whereas the surface runoff is very little (Leaney and Herczeg, 1995). Therefore, the above correlation coefficient between annual groundwater recharge and annual rainfall indicates that the dominating downward trend in annual groundwater recharge is caused by annual rainfall in the study domain.

\section{SUMMARY}

In this study, the WTF method was applied to estimate annual groundwater recharge at 438 groundwater monitoring bores in South Australia for the period 1970-2012. By using the nonparametric Mann-Kendall 
trend test, the spatially averaged annual groundwater recharge across the study domain exhibited a statistically significant downward trend with a trend slope of $-0.92 \mathrm{~mm} /$ year during the period 1970-2012. Moreover, the 237 groundwater monitoring bores with annual groundwater recharge data records longer than 20 years showed different long-term trends across the study domain, including 161 bores with downward trends (103 bores are statistically significant), 44 bores with upward trends (15 out of the 44 bores are statistically significant), and 32 bores without any trends. Further, a linear extrapolation of annual groundwater recharge trend suggested that it would reach the lowest recorded annual recharge by 2058 if the recent climatic trends continue over a longer period, indicating a potential threat to the hydrological and ecological regimes.

The dominating downward trends in annual groundwater recharge and annual rainfall with their statistically significant correlation coefficient indicate that the temporal changes in annual groundwater recharge are affected by annual rainfall across the study domain. To further diagnose the causes of changing annual groundwater recharge, we need to investigate other large-scale hydroclimate factors, such as evapotranspiration and surface runoff, which may be responsible for the long-term trends in annual groundwater recharge. Therefore, the study will be extended to investigate the effects of large-scale hydroclimate factors (and also soil hydraulic properties, land cover changes and groundwater pumping) using the Landscape component (AWRA-L) of the Australian Water Resources Assessment model (Vaze et al., 2013). In our preliminary investigation, the AWRA-L model has been shown to reproduce the long-term trend in annual groundwater recharge across the study domain, both in trend direction and statistical significance, which provides the opportunity to improve our understanding regarding the impact of long-term climate variability/change on groundwater recharge.

\section{ACKNOWLEDGEMENTS}

This work is carried out in CSIRO Land and Water, and is funded by the WIRADA research alliance. The authors thank CSIRO and Bureau AWRA team members for their contributions.

\section{REFERENCES}

Allison, G. B. and Hughes, M. W. (1978). The use of environmental chloride and tritium to estimate total recharge to an unconfined aquifer. Aust. J. Soil Res., 16, 181-195.

Anderson, V. G. (1945). Some effects of atmospheric evaporation and transpiration on the composition of natural water in Australia (continued): 4. underground waters in riverless areas. J. Aust. Chem. Inst., 12, 8398.

Cartwright, I. and Simmonds, I. (2008). Impact of changing climate and land use on the hydrogeology of southeast Australia. Aust. J. Earth Sci., 55, 1009-1021.

Coes, A. L., Spruill, T. B. and Thomasson, M. J. (2007). Multiple-method estimation of recharge rates at diverse locations in the North Carolina Coastal Plain, USA. Hydrogeol. J., 15, 773-788.

Crosbie, R. S., Binning, P. and Kalma, J. D. (2005). A time series approach to inferring groundwater recharge using the water table fluctuation method. Water Resour. Res., 41, W01008.

Crosbie, R. S., Pickett, T., Mpelasoka, F. S., Hodgson, G., Charles, S. P. and Barron, O.V. (2013). An assessment of the climate change impacts on groundwater recharge at a continental scale using a probabilistic approach with an ensemble of GCMs. Climatic Change, 117 (1-2), 41-53.

Crosbie, R. S., Davies, P., Harrington, N. and Lamontagne, S. (2015). Ground truthing groundwater recharge estimates derived from remotely sensed evapotranspiration: a case in South Australia. Hydrogeol. J., 23(2), $335-350$

Cuthbert, M. O. (2010). An improved time series approach for estimating groundwater recharge from groundwater level fluctuations. Water Resour. Res., 46(9): W09515.

Delin, G. N., Healy, R. W., Lorenz, D. L. and Nimmo, J. R. (2007). Comparison of local- to regional-scale estimates of ground-water recharge in Minnesota, USA. J. Hydrol., 334, 231-249.

Donohue, R. J., McVicar, T. R. and Roderick, M. L. (2010). Assessing the ability of potential evaporation formulations to capture the dynamics in evaporative demand within a changing climate. J. Hydrol., 386(1-4), 186-197.

Gerhart, J. M. (1986). Ground water recharge and its effects on nitrate concentration beneath a manured field site in Pennsylvania. Ground Water, 24, 483-489. 
Hall, D. W. and Risser, D. W. (1993). Effects of agricultural nutrient management on nitrogen fate and transport in Lancaster County, Pennsylvania. Water Resour. Bull., 29, 55-76.

Healy, R. W. and Cook, P. G. (2002). Using groundwater levels to estimate recharge. Hydrogeol. J. 10(1): 91-109.

Healy, R. W. (2010). Estimating Groundwater Recharge. pp.245. Cambridge University Press, Cambridge.

Jones, D. A., Wang, W. and Fawcett, R. (2009). High-quality spatial climate datasets for Australia. Aust. Meteorol. Oceanogr. J., 58(4), 233-248.

Leaney, F. W. and Herczeg, A. L. (1995). Regional recharge to a karst aquifer estimated from chemical and isotopic composition of diffuse and localised recharge, South Australia. J. Hydrol., 164(1-4), 363-387.

Lee, J. Y., Yi, M. J. and Hwang, D. (2005). Dependency of hydrologic responses and recharge estimates on water-level monitoring locations within a small catchment. Geosciences J., 9, 277-286.

Mann, H. B. (1945). Nonparametric tests against trend. J. Econom. Sci., 245-259.

Meinzer, O. E. and Stearns, N. D. (1929). A study of groundwater in the pomperaug basin, Conn. with special reference to intake and discharge, US Geol. Surv. Water Supply Paper.

Radford, B. J., Silburn, D. M. and Forster, B. A. (2009). Soil chloride and deep drainage responses to land clearing for cropping at seven sites in central Queensland, northern Australia, J. Hydrol., 379, 20-29.

Rasmussen, W. C. and Andreasen, G. E. (1959). Hydrologic budget of the beaverdam creek basin, Maryland. US Geological Survey Water Supply Paper 1472.

Scanlon, B. R., Dutton, A. and Sophocleous, M. (2003). Groundwater recharge in Texas. Report. Texas Water Dev. Board, Austin, TX. 80 pp.

Sen, P. K. (1968). Estimates of the regression coefficient based on Kendall's tau. J. Am. Stat. Assoc., 13791389.

Vaze, J., Viney, N., Stenson, M., Renzullo, L., Van Dijk, A., Dutta, D., Crosbie, R., Lerat, J., Penton, D., Vleeshouwer, J., Peeters, L., Teng, J., Kim, S., Hughes, J., Dawes, W., Zhang, Y., Leighton, B., Perraud, J. M., Joehnk, K., Yang, A., Wang, B., Frost, A., Elmahdi, A., Smith, A. and Daamen, C. (2013). The Australian Water Resource Assessment System (AWRA). Proceedings of the 20th International Congress on Modelling and Simulation (MODSIM2013), Adelaide, Australia, 1-6 December 2013.

Wohling, D. (2008). Minimising salt accession to the south east of South Australia: the border designated area and hundred of Stirling salt accession projects, vol 2-analytical techniques, results and management implications. DWLBC report 2008/23. South Australian Department of Water, Land and Biodiversity Conservation, Adelaide, Australia.

Wood, W. W. (1999). Use and misuse of the chloride mass balance method in estimating ground water recharge. Ground Water, 37, 2-3.

Wood, C. (2010). South East National Water Initiative Sub Program 1.1: improved estimates of groundwater recharge in South East South Australia, DWLBC report (Draft). South Australian Department of Water, Land and Biodiversity Conservation, Adelaide, Australia.

Zhang, L., Brutsaert, W., Crosbie, R. S. and Potter, N. (2014). Long-term annual groundwater storage trends in Australian catchments. Advances in Water Resources, 74, 156-165. 